\title{
КУЧИН АЛЕКСАНДР ВАСИЛЬЕВИЧ
}

31 мая 2014 г. исполняется 65 лет директору Института химии Коми НЦ УрО РАН Александру Васильевичу Кучину. Александр Васильевич родился в Баку в 1949 г. В 1971 г. - окончил Уфимский нефтяной институт. В 1971 г. был распределен в Институт химии Башкирского филиала АН СССР (сейчас Институт органической химии Уфимского научного центра РАН), где проработал до 1990 г. В 1990 г. избран заведующим отделом химии Коми научного центра УрО РАН, с 1995 г. является директором Института химии Коми НЦ УрО РАН. В 1976 г. защитил диссертацию на соискание ученой степени кандидата химических наук, в 1989 г. - докторскую диссертацию, в 1997 г. получил звание профессора по специальности «Органическая химия». В 2000 г. избран членомкорреспондентом РАН. А.В. Кучин - известный ученыйхимик, автор более 670 научных работ, в том числе 98 авторских свидетельств и патентов РФ.

Александр Васильевич Кучин - ведущий специалист в области органического и металлоорганического синтеза, внесший существенный вклад в развитие химии и технологии алюминийорганических соединений. Он является одним из пионеров широкого использования алюми-

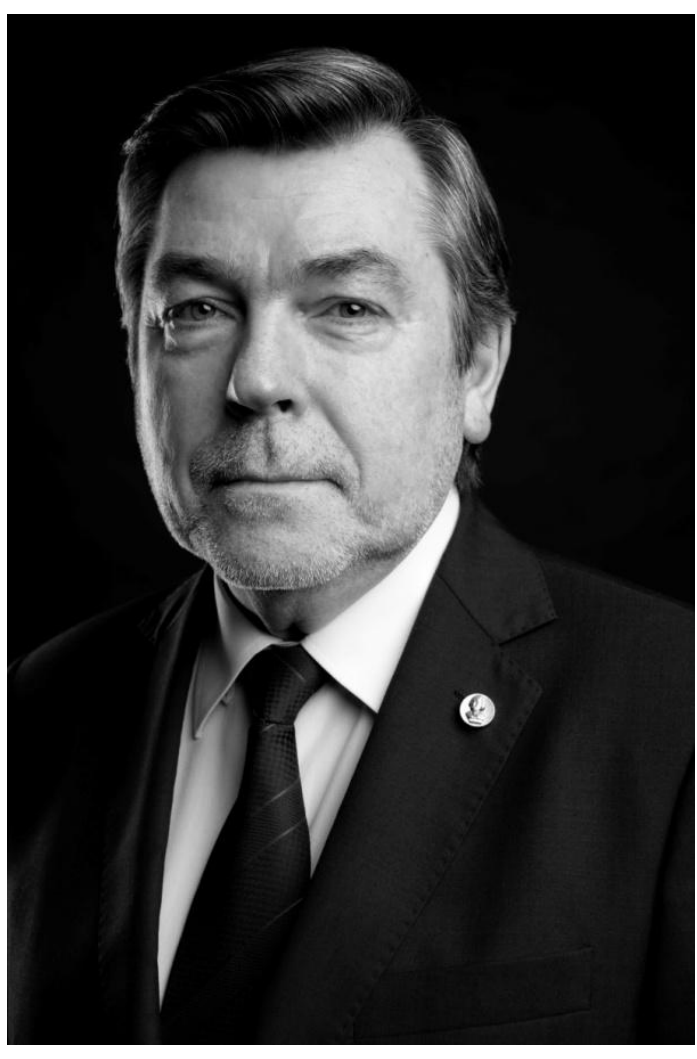
нийорганических соединений (АОC) как реагентов в тонком органическом синтезе. Им разработаны новые методы синтеза кетонов, алленов, аллильных спиртов, аминов, кислот, эфиров, сульфидов и других соединений; открыты перегруппировки, протекающие под действием АОС; предложены реагенты гидроалюминирования с уникальной активностью и селективностью; найдены методы стереоселективного восстановления кетонов. Предложенные методы нашли широкое применение в полном синтезе феромонов, простагландинов, лейкотриенов и других низкомолекулярных биорегуляторов. Под его руководством разработаны научные основы переработки продуктов лесохимии для получения биологически активных веществ. Предложен оригинальный способ комплексной переработки древесной зелени, позволяющий повысить выход экстрактивных веществ в два-три раза по сравнению с известными методами. Впервые показано положительное влияние низкомолекулярных компонентов древесной зелени пихты на продуктивность сельскохозяйственных животных. Выполнен цикл работ и предложены препараты ростостимулирующего и фунгицидного действия на основе древесной зелени ели и пихты. Разработаны высокоэффективные способы очистки сульфатного скипидара, выделения полипренолов из сульфатного мыла. Для селективного окисления S,O и N-содержащих соединений предложены диоксид хлора и методы его использования. Открыты новые методы асимметрического синтеза и получены уникальные хиральные молекулы с высокой физиологической активностью. Синтезированы фармакологические субстанции на основе терпенофенолов, обладающие комплексным влиянием на гемореологию, сосудисто-тромбоцитарный гемостаз и антиоксидантной активностью, нейропротективной, ретинопротекторной активностью, а также влияющие на мозговой кровоток. С целью создания новых фармакологически активных производных растительных полисаха- 
ридов и полимерных систем для транспорта низкомолекулярных фармакофоров получены поликатионные и полианионные модификации линейных полисахаридов.

А.В. Кучин награжден медалью ордена «За заслуги перед Отечеством» II степени (1999 г.), Почетной грамотой Республики Коми (2005 г.), премией Правительства Республики Коми им. П.А. Сорокина (2006 г.), премией Правительства Республики Коми в области научных исследований (2010 г.), Орденом Дружбы (2010 г.), Почетной грамотой Министерства экономического развития Республики Коми (2013 г.).

А.В. Кучин внес значительный вклад в создание и развитие Института химии Коми научного центра УрО РАН, является основателем признанной научной школы «Научные основы химии и технологии комплексной переработки растительного сырья», созданной в 1994 г.

Сегодня научная школа под руководством чл.-корр. РАН Кучина А.В. насчитывает 59 исследователей, из них 29 специалистов моложе 39 лет, 4 доктора наук, 21 кандидата наук, 13 аспирантов, 2 соискателя. Основные направления научной деятельности коллектива: научные основы химии и технологии комплексной переработки растительного сырья; получение физиологически активных веществ на основе функциональных производных изопреноидов, липидов и природных порфиринов; органический синтез новых веществ и материалов, асимметрический синтез.

Научная школа неоднократно была поддержана Грантом Президента РФ, отмечена gравительственными наградами за научные достижения: премией Правительства Республики Коми им. П.А. Сорокина (2006 г.), премиями Правительства РК в области фундаментальных научных исследований (2010, 2012, 2013 гг.); научными премиями: премия РАН им. А.Н. Несмеянова (1999 г.), премия УрО РАН им. академика И.Я. Постовского (2012 г.). Молодые ученые коллектива поддерживаются премиями и стипендиями Правительства Республики Коми в области научных исследований, грантами Президента РФ для поддержки молодых российских ученых.

Под научным руководством А.В. Кучина защищено 3 докторские и 18 кандидатских диссертаций, проходят обучение 6 аспирантов.

Коллектив научной школы является неизменным организатором Всероссийской научной конференции «Химия и технология растительных веществ».

Сотрудники Института химии, коллеги, члены редакционной коллегии журнала «Химия растительного сырья», друзья сердечно поздравляют Александра Васильевича с юбилеем и желают здоровья на долгие года, благополучия, творческих успехов, талантливых учеников.

Коллектив Института химии, коллеги, ученики, редколлегия журнала «Химия растительного сырья» 